\title{
Prevalence and severity of acne vulgaris and its impact on quality of life in
}

\section{adolescents}

\section{Prevalência e gravidade de acne vulgaris e seu impacto na qualidade de vida em adolescentes \\ Prevalencia y severidad del acné vulgaris y su impacto en la calidad de vida en adolescentes}

Ludmilia Rodrigues Lima Neuenschwander Penha

ORCID: https://orcid.org/0000-0001-8128-847X Ceuma University, Brazil

E-mail: ludpenha@gmail.com

Rosely Fontes Grisotto

ORCID: https://orcid.org/0000-0002-4235-0063 Ceuma University, Brazil

E-mail: rosely.grisotto@gmail.com

Aldair Darlan Santos-de-Araújo

ORCID: https://orcid.org/0000-0001-6436-9059

Federal University of São Carlos, Brazil

E-mail: aldairdarlan1@gmail.com

Caio Rodriguez Lima Neuenschwander Penha

ORCID: https://orcid.org/0000-0002-8186-9618 Ceuma University, Brazil

Ilana Mirian Almeida Felipe

ORCID: https://orcid.org/0000-0002-3265-4688 Ceuma University, Brazil

E-mail: ilanamirian@usp.br

Adriana Sousa Rêgo

ORCID: http://orcid.org/0000-0002-2494-030X Ceuma University, Brazil

E-mail: adricefs@yahoo.com.br

Sarah Tarcisia Rebelo Ferreira de Carvalho

ORCID: https://orcid.org/0000-0002-6041-3320

Ceuma University, Brazil

E-mail: sarahtrfc@hotmail.com

Solange Negreiros de Almeida Bacelar ORCID: https://orcid.org/0000-0002-5679-6189 Ceuma University, Brazil E-mail: solange.bacelar@ceuma.br

Daniela Bassi-Dibai

ORCID: https://orcid.org/0000-0002-6140-0177 Ceuma University, Brazil

E-mail: danielabassifisio@gmail.com

\begin{abstract}
Acne is a genetic-hormonal condition characterized by moderate to severe blemishes that occur due to the buildup of sebum on hair follicles through follicular hyperkeratinization. It may be inflammatory or non-inflammatory and is self-limiting, meaning that it tends to evolve to resolution naturally. However, more severe cases may require prolonged treatment to avoid the aggravation of the condition and permanent scars. The objective this study was evaluate the impact of acne on the quality of life of adolescents and determine associations with lifestyle and eating habits. A descriptive, analytical, cross-sectional study was conducted with Brazilian adolescents aged 14 to 18 years at public schools. Data collection involved the administration of a questionnaire addressing socio-demographic information, the Global Acne Grading System (GAGS) and the Cardiff Acne Disability Index (CADI). The prevalence of acne was $100 \%$. According to the GAGS, $76.63 \%$ had mild acne, $21.99 \%$ had moderate acne and $1.37 \%$ severe acne. Based on the CADI score, $70.45 \%$ of the sample had mild impact, $25.12 \%$ had moderate impact and $3.44 \%$ had severe impact. The statistical analysis of these variables revealed significant results $(p<0.05)$, but Pearson's coefficient revealed a weak correlation $(\mathrm{r}=0.265)$. The present findings demonstrate that the impact of acne on the quality of life of adolescents is directly proportional to its severity. It is necessary to disseminate knowledge on the issue to the population to reduce the impact of this condition.
\end{abstract}

Keywords: Acne vulgaris; Dermatological diseases; Quality of life. 


\begin{abstract}
Resumo
Acne é uma condição genético-hormonal caracterizada por manchas moderadas a graves que ocorrem devido ao acúmulo de sebo nos folículos capilares por meio da hiperqueratinização folicular. Pode ser inflamatório ou não inflamatório e é autolimitado, o que significa que tende a evoluir para resolução naturalmente. No entanto, os casos mais graves podem exigir tratamento prolongado para evitar o agravamento da condição e cicatrizes permanentes. $\mathrm{O}$ objetivo deste estudo foi avaliar o impacto da acne na qualidade de vida de adolescentes e determinar associações com estilo de vida e hábitos alimentares. Estudo descritivo, analítico e transversal realizado com adolescentes brasileiros de 14 a 18 anos de escolas públicas. A coleta de dados envolveu a aplicação de um questionário com informações sociodemográficas, o Global Acne Grading System (GAGS) e o Cardiff Acne Disability Index (CADI). A prevalência de acne foi de $100 \%$. De acordo com o GAGS, 76,63\% tinham acne leve, 21,99\% acne moderada e 1,37\% acne grave. Com base no escore CADI, 70,45\% da amostra apresentou impacto leve, 25,12\% impacto moderado e 3,44\% impacto grave. A análise estatística dessas variáveis revelou resultados significativos ( $p<0,05)$, mas o coeficiente de Pearson revelou uma correlação fraca $(r=0,265)$. Os presentes achados demonstram que o impacto da acne na qualidade de vida dos adolescentes é diretamente proporcional à sua gravidade. É necessário disseminar o conhecimento sobre o tema para a população para diminuir o impacto dessa condição.
\end{abstract}

Palavras-chave: Acne vulgaris; Doenças dermatológicas; Qualidade de vida.

\title{
Resumen
}

El acné es una condición genético-hormonal caracterizada por imperfecciones de moderadas a severas que ocurren debido a la acumulación de sebo en los folículos pilosos a través de la hiperqueratinización folicular. Puede ser inflamatorio o no inflamatorio y es autolimitado, lo que significa que tiende a evolucionar hasta resolverse de forma natural. Sin embargo, los casos más graves pueden requerir un tratamiento prolongado para evitar el agravamiento de la afección y las cicatrices permanentes. El objetivo de este estudio fue evaluar el impacto del acné en la calidad de vida de los adolescentes y determinar asociaciones con el estilo de vida y los hábitos alimentarios. Estudio descriptivo, analítico y transversal realizado con adolescentes brasileños de 14 a 18 años de escuelas públicas. La recogida de datos implicó la aplicación de un cuestionario con información sociodemográfica, el Global Acne Grading System (GAGS) y el Cardiff Acne Disability Index (CADI). La prevalencia de acné fue del 100\%. Según el GAGS, el 76,63\% tenía acné leve, el 21,99\% acné moderado y el 1,37\% acné severo. Según el puntaje CADI, el $70,45 \%$ de la muestra tuvo un impacto leve, el $25,12 \%$ un impacto moderado y el 3,44\% un impacto severo. El análisis estadístico de estas variables reveló resultados significativos ( $p<0,05)$, pero el coeficiente de Pearson reveló una correlación débil ( $\mathrm{r}=0,265)$. Los presentes hallazgos demuestran que el impacto del acné en la calidad de vida de los adolescentes es directamente proporcional a su gravedad. Es necesario difundir el conocimiento sobre el tema a la población para reducir el impacto de esta condición.

Palabras clave: Acne vulgaris; Enfermedades dermatológicas; Calidad de vida.

\section{Introduction}

According to the Global Burden of Diseases study, acne affects approximately $85 \%$ of the population between 10 and 20 years of age throughout the world and is one of the most common dermatological conditions (Lynn et al., 2016). Acne is a genetic-hormonal condition characterized by moderate to severe blemishes that occur due to the buildup of sebum on hair follicles through follicular hyperkeratinization. It may be inflammatory or non-inflammatory and is self-limiting, meaning that it tends to evolve to resolution naturally. However, more severe cases may require prolonged treatment to avoid the aggravation of the condition and permanent scars (Brito et al., 2010).

Clinically, acne is classified based on severity: Grade I (non-inflammatory comedogenic), characterized by open (blackhead) or closed (whitehead) comedos; Grade II (inflammatory papulose acne), characterized by open and closed comedos as well as papules and inflammatory reactions; Grade III (inflammatory nodulocystic acne), characterized by small or large nodules, cysts, pustules and papules; Grade IV (conglobate acne), characterized by all previously cited lesions as well as deep scars and severe inflammatory reaction; 5) Grade V (fulminant acne), in which pustules and nodules can progress to ulcers and the condition may be accompanied by joint pain, fever and inflamed painful lesions (Freedberg et al. 1999).

Acne is typically found in adolescents, is highly prevalent (85\%) and affects both sexes. It generally affects girls earlier (around 14 years of age) than boys (around 16 years of age), but boys often have more severe forms of the condition. Adolescence is a period of numerous changes in the organism from both the physical and emotional/psychological standpoints. It is also one of the phases in life in which one's appearance is very important. Thus, any negative impact on esthetics due to 
skin alterations can make an adolescent insecure, shy, depressed and unhappy, lowering his/her self-esteem, which can have serious consequences that may persist throughout the rest of the person's life (Ribas et al., 2008).

Adolescence is a period of considerable instability as well as physical and psychological transformations. This instability is promoted by the hormonal influence of the growth and maturation process, which provokes the etiopathogenic factors of acne, such as sebaceous hyperplasia, changes in follicular keratinization, colonization by Propionibacterium acne and the release of inflammatory mediators (Pawin et al, 2004).

There are no reports of mortality related to acne, but there is significant physical and psychological morbidity. In some cases, a lack of adequate treatment can lead to the development of scars, which, although do not affect general health, can have a negative psychological impact, with a potential reduction in quality of life (Steiner et al., 2003). The psychosocial effects of acne have been scientifically proven and studies have demonstrated that treatment leads to benefits in this regard (Grando et al., 2016; Fakour et al., 2014).

According to the literature, depression is one of the most common psychiatric disorders in dermatology, affecting 25 to $40 \%$ of patients. Thus, dermatologists and other health professionals should be attentive to depressive symptoms, as more severe cases can result self-deprecating feelings, which are reinforced by the comments of others and experiences of interpersonal rejection (Ribas et al., 2008; Knobel et al., 1977).

As acne is associated with psychiatric disorders and has the potential to affect quality of life, the aim of the present study was to evaluate the impact of acne on the quality of life of adolescents at public schools and associations with lifestyle and eating habits.

\section{Methodology}

An analytical, cross-sectional study was conducted. The population of the present study was composed of male and female adolescents enrolled at three public high schools between March and October 2018. The sample size was calculated based on a universe of 35,725 students (according to the 2018 state school census), a 95\% confidence level and an $80 \%$ prevalence rate of acne (based on rates described in previous studies with the same age group). A minimum sample of 245 was determined. The present study was conducted with 291 randomly selected adolescents between 14 and 18 years of age.

The inclusion criteria were age 14 to 18 years and enrollment in public high schools in the city of São Luís, Brazil. Students who voluntarily declined to participate despite their parents' written consent were excluded from the study.

A questionnaire addressing socio-demographic information was administered for the characterization of the sample. The influence of acne on self-esteem and quality of life was measured using the Brazilian version of the Cardiff Acne Disability Index (CADI), which was designed specifically for adolescents and young adults to measure disability and impact on quality of life due to acne. The CADI has five items addressing possible psychological consequences associated with acne, each with four scored response options ranging from 0 to 3 points. The total ranges from 0 to 15 points and is interpreted as follows: 0 to 5 points = mild impact; 60 to 10 points = moderate impact; and 11 to 15 points = severe impact on quality of life (Grando et al., 2016).

The Global Acne Grading System (GAGS) was used to classify the degree of acne of each adolescent. This questionnaire addresses five regions of the face (forehead, nose, chin, right cheek and left cheek) as well as the chest and back. A factor is attributed to each region based on the body surface, distribution of blemishes and density of sebaceous follicles. Each type of blemish is attributed a value from 0 to 4 points depending on its severity. The score is calculated by multiplying the factors of each region by the blemish severity score and global severity score and is given by the sum of local scores. Global scores from 1 to 18 points are considered indicative of mild acne, 19 to 30 points correspond to moderate acne, 31 to 38 points correspond to severe acne and scores higher than 39 points are indicative of very severe acne (Zohra et al., 2017). 
Numerical variables were expressed as mean and standard deviation (SD) values. Categorical variables were expressed as absolute and percentage frequencies. As the data exhibited normal distribution, Pearson's correlation coefficients were calculated to determine the strength of correlations between variables. The STATA 14.0 software (Stata Corp. College Station, Texas, USA) was used for all statistical tests, with a p-value $<0.05$ considered indicative statistical significance.

\section{Results}

Three hundred students were selected to participate in the study, but nine did not complete the questionnaires and were excluded. Thus, the sample was composed of 291 adolescents. Mean age (SD) was 16.02 (1.15) years. One hundred sixty-one $(55.33 \%)$ were girls and $130(44.67 \%)$ were males distributed equally among the schools and high school grades. The prevalence of acne was $100 \%$ (all participants had some type of blemish at the time of the evaluation). The majority was overweight $(74.57 \%)$ based on the body mass index. Acne severity was not significantly associated with age $(\mathrm{p}=0.439)$ or weight $(\mathrm{p}=0.241)($ Table 1$)$.

Table 1. Distribution of demographic variables among adolescents $(n=291)$.

\begin{tabular}{|c|c|c|c|}
\hline VARIABLES & N\% & VARIABLES & N\% \\
\hline Sex & & Grade & \\
\hline Male & $130(44.67)$ & $1^{\text {st }}$ year of high school & $98(33.68)$ \\
\hline \multirow[t]{2}{*}{ Female } & $161(55.33)$ & $2^{\text {nd }}$ year of high school & $98(33.68)$ \\
\hline & & $3^{\text {rd }}$ year of high school & $95(32.65)$ \\
\hline Age (years) & & Body mass category & \\
\hline 14 & $22(7.60)$ & Underweight & $19(6.53)$ \\
\hline 15 & $77(26.50)$ & Ideal range & $26(8.93)$ \\
\hline 16 & $87(29.90)$ & Overweight & $217(75.57)$ \\
\hline 17 & $65(22.30)$ & Grade I obesity & $24(8.25)$ \\
\hline 18 & $40(13.70)$ & Grade II obesity & $5(1.72)$ \\
\hline
\end{tabular}

Source: Authors.

Tables 2 and 3 display the frequencies of habits that may be related to the etiology, aggravation or prevention of acne, but none of the factors investigated were significantly associated with outcome in the present study.

Table 2. Lifestyle and hygiene habits.

\begin{tabular}{|ccc|}
\hline VARIABLES & Yes & $\begin{array}{c}\text { No } \\
\text { N }(\boldsymbol{\%})\end{array}$ \\
Works & $\mathbf{N}(\boldsymbol{\%})$ & $263(90.38)$ \\
\hline Smokes & $26(8.96)$ & $287(98.63)$ \\
\hline Consumes alcoholic beverages & $4(1.37)$ & $240(82.47)$ \\
\hline Uses dietary supplements & $51(17.53)$ & $235(80.76)$ \\
\hline Uses anabolic steroids & $56(19.24)$ & $279(95.88)$ \\
\hline Washes face before sleeping & $12(4.12)$ & $111(38.14)$ \\
\hline Washes hands frequently throughout day & $180(61.86)$ & $38(13.06)$ \\
\hline Uses oral anticontraception & $253(86.94)$ & $269(92.44)$ \\
\hline
\end{tabular}

\footnotetext{
Source: Authors.
} 
Table 3. Eating habits and physical activity $(\mathrm{n}=291)$.

\begin{tabular}{|ccccc|}
\hline Variables & $\begin{array}{c}\text { Never or hardly } \\
\text { ever }\end{array}$ & $\mathbf{1 - 2}$ times per week & $\begin{array}{c}\mathbf{3 - 4} \text { times per } \\
\text { week }\end{array}$ & $\begin{array}{c}>\text { >5 times per } \\
\text { week }\end{array}$ \\
\hline $\mathbf{N}(\boldsymbol{\%})$ & $\mathbf{N}(\boldsymbol{\%})$ & $\mathbf{N}(\boldsymbol{\%})$ & $\mathbf{N}(\%)$ \\
\hline $\begin{array}{c}\text { Practices physical } \\
\text { activity }\end{array}$ & $122(41.92)$ & $98(33.68)$ & $41(14.09)$ & $30(10.03)$ \\
\hline $\begin{array}{c}\text { Consumes processed } \\
\text { beverages with sugar }\end{array}$ & $33(11.34)$ & $154(52.92)$ & $66(22.68)$ & $38(13.06)$ \\
\hline $\begin{array}{c}\text { Consumes fast food } \\
\text { Consumes sweets or } \\
\text { desserts }\end{array}$ & $78(26.80)$ & $164(56.36)$ & $25(8.59)$ & $24(8.25)$ \\
\hline $\begin{array}{c}\text { Consumes vegetables, } \\
\text { legumes or fruits }\end{array}$ & $42(10.70)$ & $142(48.80)$ & $76(26.10)$ & $42(14.40)$ \\
\hline
\end{tabular}

Source: Authors.

Based on the GAGS, mild acne predominated in the sample (76.63\%), followed by moderate acne $(21.99 \%)$ and severe acne $(1.37 \%)$. Likewise, the results of the CADI demonstrated that mild impact on quality of life was predominant (70.45\%), followed by moderate impact (26.12\%) and severe impact (3.44\%).

The statistical analysis of these variables revealed significant results $(\mathrm{p}<0.05)$, but Pearson's coefficient revealed a weak correlation $(\mathrm{r}=0.265)$ (Table 4$)$.

Table 4. Pearson's correlations with Global Acne Grading Scale (GAGS).

\begin{tabular}{|lcc|} 
& \multicolumn{2}{c|}{ GAGS $^{\mathbf{a}}$} \\
& $\mathbf{r}$ & $p$ \\
\hline Age (years) & 0.045 & 0.439 \\
\hline Weight (kg) & 0.068 & 0.241 \\
\hline CADI $^{\text {b }}$ & $0.265^{*}$ & $<0.005$ \\
\hline
\end{tabular}

${ }^{a}$ Global Acne Grading System. ${ }^{\mathrm{b}}$ Cardiff Acne Disability Index. Source: Authors.

\section{Discussion}

The following were the main findings of the present study: I) the severity of acne is directly related to the severity of its impact on quality of life; II) the prevalence of acne vulgaris among adolescents 14 to 18 years of age was $100 \%$; III) although all the adolescents had acne, the majority had mild to moderate degrees of the condition; and IV) the majority of adolescents consumed processed beverages with sugar and fast food one to two times per week. Thus, the analysis of the results revealed a negative impact on quality of life caused by the psychological consequences of acne and the impact was proportional to severity.

The impact on quality of life was directly related to the severity of acne measured using the GAGS, as a positive correlation was found between the GAGS and CADI scores. Among the participants, 70.45\% reported a mild impact on quality of life. This finding is similar to results reported in previous studies. Taborda et al. (2010) evaluated the impact on quality of life of patients with different dermatoses and found that $74.3 \%$ of those with acne reported a mild impact on quality of life. Analyzing adolescents with a average age of 16 years using the Children`s Dermatology Life Quality Index, Vilar et al. (2015) 
found that the majority had mild acne (65\%), which had an important negative impact on quality life. In a study conducted in Greece with 1531 adolescents 11 to 19 years of age, Tasoula et al. (2012) found that $71.2 \%$ of the cases of acne were mild and the negative impact on quality of life was proportional to the severity of the condition.

Acne is highly prevalent in adolescents and young adults. Indeed, the prevalence in the present study was $100 \%$. Studies in the literature report similar findings, such as $96 \%$ of 452 adolescents 10 to 17 years of age in a study conducted by Bagatin et al. (2014) in the city of São Paulo, Brazil, 82.4\% of adolescents 10 to 12 years of age in a study conducted in Portugal by Amado et al. (2006) and 95\% of adolescents 12 to 20 years of age in a study conducted in Sweden by Nijsten et al. (2007).

Adolescence is a period of transition in which an individual begins to acquire a new status in society and when certain values are given extreme importance by the majority, such as physical appearance and peer acceptance. Thus, although acne is considered a self-limiting dermatological condition of generally low severity, it can have permanent effects on the lives of individuals not only in terms of esthetic issues, but also resulting from feelings of self-deprecation and interpersonal rejection.

In recent decades, attempts have been made to demonstrate a direct relation between diet and the severity of acne, but conflicting results are found in the literature. In the present study, the analysis of eating habits, dietary supplements and anabolic steroids revealed no significant associations with the presence or severity of acne in the individuals evaluated. This absence of an association may be related to the study design as well as the small number of participants who frequently used foods linked to the emergence of acne, such as products with a high glycemic index and dairy products (Costa et al., 2010; Silva et al., 2018).

Like dietary habits, the body mass index (BMI) has been extensively studied as a component associated with the severity of acne due to the physiological changes caused by the increase in body fat. The source of peripheral androgenic production is fat tissue, which is increased in obese individuals, and an increase in the activity of sebaceous glands is a known effect of hyperandrogenism (Pappas, 2009; Comin \& Santos, 2011). However, divergent opinions are found regarding the association between an increase in the BMI and the severity of acne, as such as association has been found in some studies, but not in others. In the present study, approximately $85 \%$ of the participants exhibited overweight or Grades I and II obesity (only $6.5 \%$ were underweight) and no significant association was found between BMI and the severity of acne (Neupane, 2018).

\section{Conclusion}

In conclusion, the prevalence of acne was very high among the adolescents analyzed in the present study (100\%) and the impact on quality of life was directly proportional to the severity of the condition. The dissemination of knowledge through lectures and pamphlets on causal factors, factors related to the improvement or aggravation of acne and possible psychological impacts on adolescents would be an important step toward reducing the negative influence of acne on the quality of life of this population. Considering the limitation of this study having reached a restricted public in a single city, it is suggested that future research can be designed in order to reach a larger public and counting on the participation of several cities from different regions of the country.

\section{Acknowledgments}

Thanks to the University CEUMA (São Luís - MA, Brazil), to the Graduate Program in Management of Health Programs and Services and to Professor Ph.D Daniela Bassi-Dibai for her efforts. 


\section{References}

Amado, J., Matos, M. E., Abreu, A. M., Loureiro, L., Oliveira, J., Verde, A, et al. (2006). The prevalence of acne in the north of Portugal. J Eur Acad Dermatol Venereol. 20:1287-95. https://doi.org/10.1111/j.1468-3083.2006.01791.x.

Bagatin, E., Timpano, D. L., Guadanhim, L. R. S., Nogueira, V. M. A., Terzian, L. R., Steiner, D, et al. (2014). Acne vulgaris: prevalence and clinical forms in adolescents from Sao Paulo, Brazil. An Bras Dermatol. 89:428-35. https://doi.org/10.1590/abd1806-4841.20142100

Brito, M. F. M., Pessoa, I. S., Galindo, J. C. S., Rosendo, L. H. P. M. \& Santos, J. B. (2010). Avaliação dos efeitos adversos clínicos e alterações laboratoriais em pacientes com acne vulgar tratados com isotretinoína oral. An Bras Dermatol. 85:331-7. https://doi.org/10.1590/S0365-05962010000300006.

Comin, A. F. \& Santos, Z. E. A. (2011). Relação entre carga glicêmica da dieta e acne. Sci Med. 21:37-43.

Costa, A., Lage, D. \& Moisés, T. A. (2010). Acne e dieta: verdade ou mito? An Bras Dermatol. 85:346-53. https://doi.org/10.1590/S036505962010000300008 .

Fakour, Y., Noormohammadpour, P., Ameri, H., Ehsani, A. H., Mokhtari, L., Khosrovanmehr, N., et al (2014). The effect of isotretinoin (roaccutane) therapy on depression and quality of life of patients with severe acne. Iran J Psychiatry. 9:237-40.

Freedberg, I. M., Eisen, A. Z., Wolf, K., Austein, K. F., Goldsmith, L. A. \& Katz, S. L (1999). Fitzpatrick's dermatology in general medicine. 5th ed. New York: McGraw-Hill.

Grando, L. R., Horn, R., Cunha, V. T., \& Cestari, T. F (2016). Translation, cultural adaptation and validation for Brazilian Portuguese of the Cardiff Acne Disability Index instrument. An Bras Dermatol. 91:180-6. https://doi.org/10.1590/abd1806-4841.20164402.

Knobel, M. El síndrome de la adolescência normal (1977). In: Aberastury A, Knobel M. La adolescência normal. Paidos.

Lynn, D. D., Umari, T., Dunnick, C. \& Dellavalle, L. P (2016). The epidemiology of acne vulgaris in late adolescence. Adolesc Health Med Ther. 7:13-25. https://dx.doi.org/10.2147\%2FAHMT.S55832.

Neupane, S., Basnet, B. \& Sharma, T (2018). Association between Acne and Body Mass Index: A Hospital Based Cross Sectional Study. NJDVL.16:53-6. http://dx.doi.org/10.3126/njdvl.v16i1.19408.

Nijsten, T., Rombouts, S. \& Lamber, J (2007). Acne is prevalent but use of its treatments is infrequent among adolescents from the general population. $J$ Eur Acad Dermatol Venereol. 21:163-8. https://doi.org/10.1111/j.1468-3083.2006.01829.x.

Pappas, A. (2009). The relationship of diet and acne: A review. Dermatoendocrinol. 1:262-7. https://dx.doi.org/10.4161\%2Fderm.1.5.10192.

Pawin, H., Beylot, C., Chivot, M., Faure, M., Poli, F., Revuz, J., et al. (2004). Physiopathology of acne vulgaris: recent data, new understanding of the treatments. Eur J Dermatol. 14:4-12.

Ribas, J., Oliveira, C. M. P. B. \& Ribeiro, J. C. S. (2008). Acne vulgar e bem-estar em acadêmicos de medicina. An Bras Dermatol. 83:520-5. https://doi.org/10.1590/S0365-05962008000600004.

Silva, M. A. \& Sany, N. D. (2018). Estudo da relação entre a alimentação e a acne vulgar. Cadernos UniFOA. 12:123-33. https://doi.org/10.47385/cadunifoa.v12.n35.422.

Steiner, D., Bedin, V. \& Melo, S. J. S (2003). Acne vulgar. Rev Bras Med. 60:489-95.

Taborda, M. L., Weber, M. B., Teixeira, K. A. M., Lisboa, A. P. \& Welter, E. Q. (2010). Avaliação da qualidade de vida e do sofrimento psíquico de pacientes com diferentes dermatoses em um centro de referência em dermatologia no sul do país. An Bras Dermatol. 85:52-6. https://doi.org/10.1590/S036505962010000100007

Tasoula, E., Gregoriou, S., Chalikias, J., Lazarou, D., Danopoulou, I., Katsambas, A., et al. (2012) The impact of acne vulgaris on quality of life and psychic health in young adolescents in Greece. Results of a population survey. An Bras Dermatol. 87:862-9. https://doi.org/10.1590/S0365-05962012000600007.

Vilar, G. N., Santos, L. A., \& Sobral Filho, J. F. (2015). Quality of life, self-esteem and psychosocial factors in adolescents with acne vulgaris. An Bras Dermatol. 90:622-9. https://doi.org/10.1590/abd1806-4841.201533726.

Zohra, F. T., Sultana, T., Islam, S. \& Nasreen, T. (2017) Evaluation of Severity in Patients of Acne Vulgaris by Global Acne Grading System in Bangladesh. Clinical Pathology \& Research Journal. 1:000105. http://dx.doi.org/10.23880/cprj-16000105. 